\title{
Iranian EFL engineering students` motivational orientations towards english language learning along gender and further education in language institutes.
}

\begin{abstract}
The aim of the present study was to understand motivational orientations of the Iranian EFL engineering students towards the language and their attitudes towards learning English, English-speaking people and their culture. To do this end, all 596 engineering students taking general English course in engineering faculty of Tabriz Azad University (different engineering majors) were selected based on random sampling. Gardner's 104-item AMTB (Attitude, Motivation Test Battery) questionnaire was administered to the selected respondents. All 12 domains were considered. Furthermore there was an attempt to understand whether any statistically significant differences existed due to the participants' gender and further education in foreign language institutes or not. The results of the study showed that engineering students in the present study learn the English language both instrumentally and integratively and they have positive attitudes towards the target language community and its members. Furthermore, gender and further education in language institutes affected some motivational orientations and attitude domains significantly. Those with further education in language institutes were more motivated and the level of their anxiety was lower. The study concluded with some pedagogical implications.
\end{abstract}

Keyword: AMTB; Motivation; Attitude; Iranian EFL engineering students. 